\title{
De Novo Sequencing of Neuropeptides Using Reductive Isotopic Methylation and Investigation of ESI QTOF MS/MS Fragmentation Pattern of Neuropeptides with N-

\author{
Terminal Dimethylation
} \\ Qiang $\mathrm{Fu}^{\dagger}$ and Lingjun $\mathrm{Li}^{\dagger, \ddagger \text {,* }}$
}

School of Pharmacy ${ }^{\ddagger}$ and Department of Chemistry ${ }^{\dagger}$, University of Wisconsin at Madison, Madison, Wisconsin 53705-2222, USA.

1li@pharmacy.wisc.edu.

\begin{abstract}
A stable-isotope dimethyl labeling strategy was previously shown to be a useful tool for quantitative proteomics. More recently, $\mathrm{N}$-terminal dimethyl labeling was also reported for peptide sequencing in combination with database searching. Here, we extend these previous studies by incorporating $\mathrm{N}$-terminal isotopic dimethylation for de novo sequencing of neuropeptides directly from tissue extract without any genomic information. We discovered several new sequencing applications of this method in addition to the identification of the $\mathrm{N}$ terminal residue using the enhanced a1 ion. The isotope labeling also provides easier and more confident de novo sequencing of the complete peptide sequences by comparing similar MS/MS fragmentation patterns of the isotopically labeled peptide pairs. The current study on neuropeptides shows several distinct fragmentation pattern changes after $\mathrm{N}$-terminal dimethylation which have not been reported previously. The $y(n-1)$ ion is enhanced in multiply charged peptides and is weak or missing in singly charged peptides. The MS/MS spectra of singly charged peptides are simplified due to the enhanced $\mathrm{N}$-terminal fragments and suppressed internal fragments. The neutral loss of dimethyl amine is also observed. The mechanisms for the
\end{abstract}


above fragmentations are proposed. Finally, the structures of the immonium ion and related ions of $\mathrm{N}^{\alpha}, \mathrm{N}^{\varepsilon}$-tetramethylated lysine and $\mathrm{N}^{\varepsilon}$-dimethylated lysine are explored. 
Table S-1. Reductive methylation of peptide standards

\begin{tabular}{|c|c|c|c|c|c|c|c|c|c|c|c|c|c|c|c|}
\hline Peptide & Buffer & $\mathrm{CH}_{2} \mathrm{O}$ & $\mathrm{SCB}$ & $t_{a}$ & $\mathrm{NH}_{3}$ & $t_{b}$ & $\Delta \mathrm{m}$ & Peptide & Buffer & $\mathrm{CH}_{2} \mathrm{O}$ & SCB & $t_{a}$ & $\mathrm{NH}_{3}$ & $t_{b}$ & $\Delta \mathrm{m}$ \\
\hline \multicolumn{8}{|l|}{ YGGFL } & \multicolumn{8}{|c|}{ DFSAWAamide } \\
\hline 5 & A-E & 1 & 1.5 & 24 & 2 & $2-8$ & 28 & 5 & $\mathrm{~B}$ & 1 & 1.5 & 24 & 2 & 13 & $28,40,58$ \\
\hline 5 & $\mathrm{~B}$ & 1 & 2.5 & 5 , & 2 & 9 & 28 & 5 & $\mathrm{~B}$ & 2 & 2 & 5 & 4 & 12 & 28 \\
\hline \multicolumn{8}{|c|}{ FMRFamide } & 5 & $\mathrm{~B}$ & 1 & 1.5 & 24 & 2 & 98 & 28 \\
\hline 5 & $\mathrm{~A}, \mathrm{E}$ & 1 & 1.5 & 14 & 2 & 12,13 & 28,58 & 5 & $\mathrm{~B}$ & 0.1 & 1.5 & 24 & 2 & 7 & $28,40,58$ \\
\hline 5 & $\mathrm{~A}, \mathrm{E}$ & 1 & 1.5 & 14 & 2 & 96 & 28 & 5 & $\mathrm{~B}$ & 0.05 & 1.5 & 24 & 2 & 9 & $28,40,58$ \\
\hline 5 & $\mathrm{~B}, \mathrm{C}, \mathrm{D}$ & 1 & 1.5 & 14 & 2 & $12,15,14$ & 28 & \multicolumn{8}{|c|}{ pyrTSFTPRLamide } \\
\hline 5 & $\mathrm{C}, \mathrm{D}$ & 2 & 1.5 & 24 & 2 & 14 & 28,58 & 5 & $\mathrm{~B}, 10$ & 1 & 1.5 & 24 & 2 & 14 & 0,30 \\
\hline 5 & $\mathrm{~B}$ & 2 & 2 & 16 & 2 & 12 & 28,58 & 5 & $\mathrm{~B}, 10$ & 1 & 1.5 & 24 & 2 & 99 & 0 \\
\hline 5 & $\mathrm{~B}$ & 4 & 2 & 16 & 2 & 13 & $28,58,88^{1}$ & 1 & $\mathrm{~B}$ & 2 & 1.5 & 24 & 2 & 4 & $0,30,60,90^{2}$ \\
\hline 5 & $\mathrm{~B}$ & 4 & 2 & $5^{\prime}$ & 8 & 8 & 28 & 1 & $\mathrm{~B}$ & 2 & 2 & 5 & 4 & 13 & 0,30 \\
\hline \multicolumn{8}{|c|}{ KHKNYLRFamide } & \multicolumn{8}{|c|}{ pyrLYENK } \\
\hline 5 & $\mathrm{~A}, \mathrm{E}$ & 1 & 1.5 & 14 & 2 & 16,18 & 84,$114 ; 82,112 ; 80,110 ; 78,108 ; 76,106$ & 1 & $\mathrm{~B}, 10$ & 2 & 2 & 5 , & 4 & 6 & 28 \\
\hline 5 & $\mathrm{~A}, \mathrm{E}$ & 1 & 1.5 & 14 & 2 & 97 & $84 ; 82 ; 80 ; 78 ; 76$ & \multicolumn{8}{|c|}{ NRNLRFamide } \\
\hline 5 & $\mathrm{~B}, \mathrm{C}, \mathrm{D}$ & 1 & 1.5 & 14 & 2 & $12,19,17$ & $84 ; 82 ; 80 ; 78 ; 76$ & 1 & $\mathrm{~B}, 10$ & 1 & 5 & 8 & 2 & 7 & $28 ; 26^{3}$ \\
\hline 5 & $\mathrm{~B}$ & 1 & 5 & 12 & 2 & 96 & 84 & \multicolumn{8}{|c|}{ PFCNAFTGCamide } \\
\hline 5 & $\mathrm{~B}$ & 2 & 2 & 12 & 2 & 2 & 84,$114 ; 82,112 ; 80,110$ & 1 & $\mathrm{~B}, 10$ & 1 & 5 & 8 & 2 & 3.5 & 14 \\
\hline 5 & $\mathrm{~B}$ & 2 & 2 & $5^{\prime}$ & 4 & 11 & $84,82,80,76$ & \multicolumn{8}{|c|}{ CYFQNCPRGamide } \\
\hline 5 & $\mathrm{~B}$ & 0.05 & 5 & 6 & 2 & 4 & $28,42,56,70,84$ & 1 & $\mathrm{~B}, 10$ & 1 & 5 & 8 & 2 & 52 & 28 \\
\hline 5 & $\mathrm{~B}$ & 0.0005 & 5 & 6 & 2 & 5 & 0,14 & & & & & & & & \\
\hline
\end{tabular}

The unit for the volume of the peptides, buffer, $\mathrm{CH}_{2} \mathrm{O}, \mathrm{SCB}\left(\mathrm{NaBH}_{3} \mathrm{CN}\right)$, and $\mathrm{NH}_{3}$ are all $\mu 1.5 \mu$ buffers were used for all the experiments unless specified. ' $\mathrm{B}$, 10 ' stands for $10 \mu \mathrm{l}$ of buffer B. ' $\mathrm{t}_{\mathrm{a}}$ ' is the time delay between the addition of formaldehyde and the addition of ammonia. ' $\mathrm{t}_{\mathrm{b}}$ ' is the time delay between the addition of ammonia and the LC-MS/MS acquisition time. All the peptides and modified peptides were stored at $-20^{\circ} \mathrm{C}$ before LC-MS analysis. The unit of time is hour unless specified. 5 ' stands for 5 minutes. Concentration of the peptides: YGGFL, KHKNYLRFamide, FMRFamide, pyrTSFTPRLamide, DFSAWAamide: 1mg/ml; NRNFLRFamide, pyrLYENK: 2mg/ml;

CYFENCPRGamide (with disulfide bond): $5 \mathrm{mg} / \mathrm{ml}$. Buffer A: $\mathrm{HCl}, 10^{-3} \mathrm{M}, \mathrm{pH}=3.0 ; \mathrm{Buffer} \mathrm{B}^{\mathrm{NaOAc}} / \mathrm{HOAc}_{1} 1 \mathrm{M} / 1 \mathrm{M}, \mathrm{pH}=4.8 ; \mathrm{Buffer} \mathrm{C}: \mathrm{KH} \mathrm{PO}_{4} / \mathrm{NaH}(\mathrm{PO})_{2}, 0.5 \mathrm{M} / 0.5 \mathrm{M}$, $\mathrm{pH}=7.2$; Buffer D: $\mathrm{KH}_{2} \mathrm{PO}_{4} / \mathrm{NaH}\left(\mathrm{PO}_{4}\right)_{2}, 0.1 \mathrm{M} / 1 \mathrm{M}, \mathrm{pH}=8.2$; Buffer E: $\mathrm{KH}_{2} \mathrm{PO}_{4} / \mathrm{NaH}\left(\mathrm{PO}_{4}\right)_{2}, 1 \mathrm{M} / 0.1 \mathrm{M}, \mathrm{pH}=6.2$. Formaldehyde, 37\%; Formaldehyde- $\mathrm{D}_{2}, 25 \%$; NaBH $3 \mathrm{CN}, 5 \mathrm{M}$; Ammonia: $25 \%$. ' $\Delta \mathrm{m}$ ' stands for the mass change after the reaction. The peptides with large retention time difference are separated by semicolon. ${ }^{1}:+88 \mathrm{Da}$ is from one dimethylation at $\mathrm{N}$-terminus and two methylol modifications at arginine side chain $(+28+30+30 \mathrm{Da}){ }^{2}:+90$ Da peak corresponds to the addition of 3 methylol groups to the guanidine group at the side chain of arginine. ${ }^{3}:$ The $+26 \mathrm{Da}$ is due to incomplete reduction of imine. 


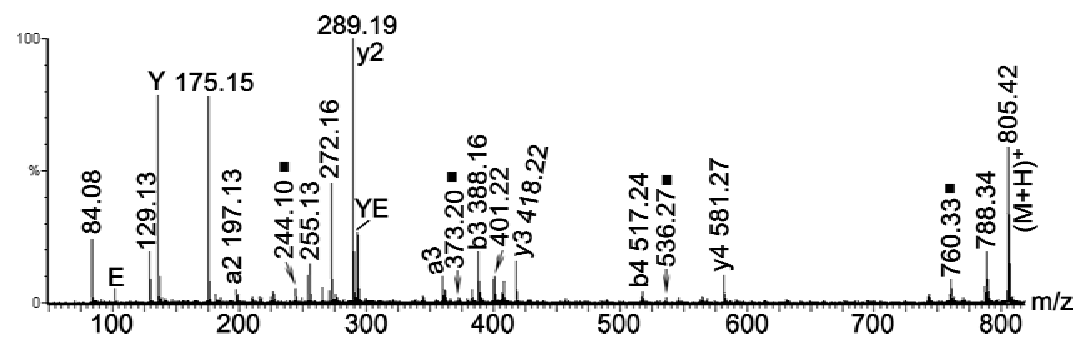

Figure S-1: The MS/MS raw data of pyrLYENK $\left(\mathrm{CH}_{3}\right)_{2}$ at $41.3 \mathrm{ev.} \mathrm{The} \mathrm{neutral} \mathrm{losses} \mathrm{of}$ dimethyl amine ions are marked by black squares. 442.10: y2-45; 373.20: y3-45; 536.27: y4-45; 760.33: $(\mathrm{M}+\mathrm{H})^{+}-45$. 

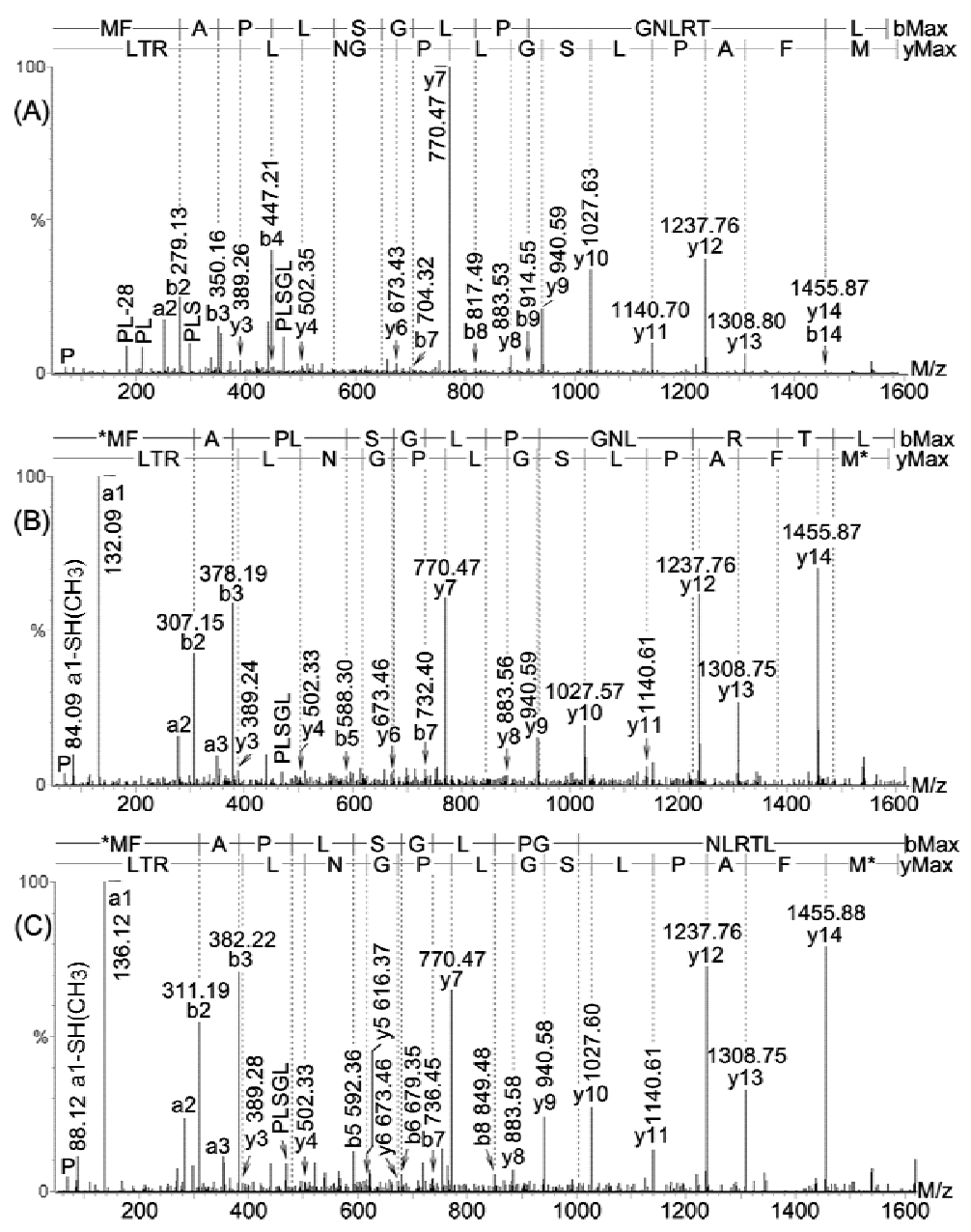

Figure S-2: The MS/MS sequencing of A) MFAPLSGLPNGLRTL $\left(793.89^{2+}\right.$ ) and B) $\left(\mathrm{CH}_{3}\right)_{2}$ MFAPLSGLPNGLRTL $\left(807.90^{2+}\right)$ and $\left.\mathrm{C}\right)\left(\mathrm{CHD}_{2}\right)_{2}$ MFAPLSGLPNGLRTL $\left(810.03^{2+}\right)$. The N-terminal dimethyl modification is labeled by an asterisk in the sequence. 